\title{
PERSPEKTIF PENINGKATAN PRODUKSI PADI DI KABUPATEN LAMONGAN
}

\author{
Alviyah Yunianti dan Elys Fauziyah \\ Prodi Agribisnis Fakultas Pertanian Universitas Trunojoyo Madura \\ E-mail: alviyah.yunianti@gmail.com, mamakayis97@gmail.com
}

\begin{abstract}
The aim of this research are to know the result of rice product forecasting at Lamongan regency in 2016 and identify the factor influence rice production. This research was done at Lamongan by using cluster method. The total number of respondents are 60 farmers. Data were analyzed with ARIMA and multiple regression method. The results show that the rice production forecasting at Lamongan in 2016 will increas approximately 1.022.488 ton, and the factors influence rice production are land area, urea, labor and capital. If each those variables are increased, it will be able to increase the result of rice production.
\end{abstract}

Keywords: rice production, forecasting, ARIMA analysis, multiple regression analysis

\begin{abstract}
Abstrak: Penelitian ini bertujuan untuk mengetahui hasil peramalan produksi padi di Kabupaten Lamongan tahun 2016 dan mengidentifikasi faktor-faktor yang mempengaruhi produksi padi di Kabupaten Lamongan. Penelitian ini dilakukan di Kabupaten Lamongan menggunakan metode cluster, dengan jumlah responden 60 petani. Analisis data menggunakan ARIMA dan regresi berganda. Hasil penelitian menunjukkan bahwa ramalan produksi padi di Kabupaten Lamongan pada tahun 2016 mengalami peningkatan sebesar 1.022.488 ton, dan faktor-faktor produksi yang mempengaruhi produksi padi di Kabupaten Lamongan adalah luas lahan, pupuk urea, tenaga kerja dan modal. Jika masing-masing variabel tersebut ditingkatkan dengan asumsi cateris paribus maka mampu meningkatkan hasil produksi padi.
\end{abstract}

Kata kunci: produksi padi, peramalan, analisis ARIMA, analisis regresi berganda

\section{PENDAHULUAN}

Pangan adalah hak asasi manusia yang harus terpenuhi untuk menjamin keberlangsungan hidupnya. Oleh karena itu keberadaan pangan dengan jumlah yang cukup dan harga yang terjangkau merupakan keinginan setiap manusia. Sehingga kewajiban bagi pemerintah adalah membuat kebijakan yang dapat menjamin ketahanan pangan serta swasembada pangan khususnya beras.

Menurut Adiratma (2004), beras mempunyai peran yang strategis baik dalam penetapan ketahanan pangan, ketahanan ekonomi, serta ketahanan politik nasional. Di Indonesia beras merupakan komoditi yang penting karena: a) beras merupakan bahan pangan dan sumber kalori utama bagi lebih dari 90 persen penduduk; b) usahatani pemberasan di Indonesia mampu menyerap tenaga kerja sebanyak 21 juta keluarga petani; dan c) kurang lebih 30 persen pengeluaran rumah tangga miskin dipergunakan untuk membeli beras (Bustaman, 2003).

Konsumsi beras di Indonesia dari waktu ke waktu mengalami peningkatan. Pada tahun 2008 jumlah konsumsi sebesar 31.799.000 ton meningkat menjadi 33.035.000 ton. Disisi lain produksi beras di Indonesia dalam kurun waktu 5 tahun (2008-2012) juga mengalami peningkatan sebesar 4.651 .000 ton.Surplus produksi beras di Indonesia, tidak mengurangi jumlah impor beras Indonesia. Jumlah impor beras cenderung mengalami kenaikan, dari 289.260 ton pada tahun 2008 menjadi 2.774.002 ton pada tahun 2011, dan tahun 2012 turun menjadi 1.927 .330 ton. Peningkatan jumlah import beras yang tajam terjadi pada tahun 2011. Jumlah impor beras mengalami kenaikan 3 kali lipat dari tahun 2010. 
Peningkatan ini dipengaruhi oleh menurunnya luas areal panen padi di Indonesia pada tahun 2011 seluas 73,191 Ha (BPS, 2012).

Salah satu pemasok beras terbesar yang ada di Indonesia adalah Jawa Timur, dimana pada tahun 2012 Jawa Timur berada pada urutan pertama sebagai provinsi penghasil produksi beras terbanyak dengan konstribusi sebesar $17,67 \%$. Di provinsi Jawa Timur produksi padi tertinggi dihasilkan oleh Kabupaten Jember, diikuti oleh Kabupaten Bojonegoro, dan peringkat ketiga adalah Kabupaten Lamongan.

Tabel 1. Produksi beras di Jawa Timur 2012

\begin{tabular}{clc}
\hline No. & Kabupaten/Kota & $\begin{array}{c}\text { Produksi Padi } \\
\text { (Juta ton) }\end{array}$ \\
\hline 1. & Jember & 153.331 \\
2. & Bojonegoro & 147.005 \\
3. & Lamongan & 140.783 \\
4. & Banyuwangi & 122.132 \\
5. & Ngawi & 112.835 \\
\hline
\end{tabular}

Sumber: Direktorat Jendral Perimbangan Keuangan, 2012

Lamongan adalah salah satu basis pertanian di Jawa Timur dengan produksi utamanya adalah padi dan jagung. Dimana luas areal panen padi adalah $138.302 \mathrm{Ha}$, sedangkan luas ereal panen jagung adalah $50.864 \mathrm{Ha}$ (BKPM, 2012). Dari luas areal panen dapat dilihat bahwa sektor pertanian didominasi oleh padi yang tersebar di semua wilayah yang ada di Kabupaten Lamongan.Data pada kurun waktu lima tahun terakhir produksi padi di Kabupaten Lamongan cenderung berfluktuasi.

Tabel 2. Produksi Padi Kabupaten Lamongan tahun 2008-2012

\begin{tabular}{cccc}
\hline Tahun & $\begin{array}{c}\text { Luas } \\
\text { Panen } \\
\text { (Ha) }\end{array}$ & $\begin{array}{c}\text { Produksi } \\
\text { (ton) }\end{array}$ & $\begin{array}{c}\text { Produktivitas } \\
\text { (ton/Ha) }\end{array}$ \\
\hline 2008 & 134.117 & 839.393 & 6,26 \\
2009 & 139.304 & 892.613 & 6,41 \\
2010 & 138.302 & 857.637 & 6,20 \\
2011 & 127.709 & 678.042 & 5,31 \\
2012 & 142.559 & 911.854 & 6,4 \\
\hline
\end{tabular}

Sumber: BPS Kabupaten Lamongan, 2013
Dalam upaya pembuatan perencanaan peningkatan produksi padi di Kabupaten Lamongan, maka diperlukan peramalan produksi padi di masa yang akan datang. Hasil peramalan ini dapat dijadikan acuan untuk pembuatan kebijakan di masa depan. Kegiatan peramalan dapat dilakukan dengan menggunakan data masa lalu (Nurhayati dkk, 2013), salah satunya adalah metode metode ARIMA karena sangat baik ketepatannya untuk peramalan jangka pendek.

Dalam pembuatan kebijakan produksi padi juga dibutuhkan informasi tentang faktorfaktor yang dapat dimobilisasi untuk peningkatan produksi padi di Kabupaten Lamongan. Sehingga tujuan dari penelitian ini adalah memprediksi produksi padi di Kabupaten Lamongan tahun 2016, dan menganalisis faktor-faktor yang mempengaruhi produksi padi di Kabupaten Lamongan.

\section{METODE PENELITIAN}

Penentuan lokasi penelitian ini dilakukan secara purposive atau sengaja di Kabupaten Lamongan, dengan pertimbangan bahwa komoditas unggulan Kabupaten Lamongan adalah padi. Hal ini ditunjukkan dari luasan areal panen padi sebesar 138.302 hektar, ini . Selain itu Kabupaten Lamongan menempati urutan sebagai produksi padi tertinggi di Jawa Timur dengan jumlah produksi sebesar 140.783 juta ton

Penentuan sampel pada penelitian ini menggunakan metode cluster. Menurut Singarimbun dan Effendi (2008), metode ini merupakan metode dimana pengambilan sampel dilakukan secara bertahap berdasarkan wilayah-wilayah yang ada. Tahap pertama yaitu menetapkan satu kecamatan sampel yaitu Kecamatan Sugio dengan pertimbangan bahwa Kecamatan Sugio adalah kecamatan dengan produksi padi tertinggi yang ada di Kabupaten Lamongan. Tahap kedua, dengan terpilihnya Kecamatan Sugio sebagai sampel maka langkah selanjutnya yaitu memilih desa sampel, dilihat dari luas areal panen padi maka terpilihlah tiga desa dengan dengan luas areal panen padi tertinggi yaitu Desa Sekarbagus, Desa Jubel Kidul dan Desa German, dengan luas areal masing-masing sebesar $884 \mathrm{Ha}, 813$ Ha dan 758 Ha. 
Jumlah sampel penelitian sebanyak 60 petani yang diambil dari tiga desa terpilih masing-masing 20 petani dengan teknik incidental sampling.

Dalam penelitian ini menggunakan dua macam metode pengambilan data yaitu data primer dan data sekunder. Data primer ini digunakan untuk menganalisis faktor-faktor yang mempengaruhi produksi padi di Kabupaten Lamongan. Data sekunder dalam penelitian ini berupa data time series produksi padi Kabupaten Lamongan dari tahun 1983 sampai 2012. Data time series ini digunakan untuk meramalkan produksi padi di Kabupaten Lamongan tahun 2016.

Metode yang dipergunakan untuk metode yang pertama adalah metode peramalan ARIMA. Dalam membuat model ARIMA menurut Hossain et. al. (2012), ada empat langkah yaitu :identifikasi Model, estimasi Model, evaluasi Model dan peramalan dengan Model. Sedangkan untuk tujuan penelitian yang kedua dianalisis dengan menggunakan fungsi produksi Cobb-Douglas, dengan model sebagai berikut :

$$
\begin{array}{ll}
\mathrm{Q}=\mathrm{A} & \mathrm{L}^{\beta 1} \mathrm{P}_{\text {Urea }}^{\beta 2} \mathrm{TK}^{\beta 3} \mathrm{M}^{\beta 4} \\
\text { Dimana } & \text { : } \\
\mathrm{Q} & =\text { hasil produksi } \\
\mathrm{L} & =\text { luas lahan } \\
\mathrm{P}_{\text {Urea }} & =\text { pupuk urea } \\
\mathrm{TK} & =\text { tenaga kerja } \\
\mathrm{M} & =\text { modal } \\
\varepsilon & =\text { error term }
\end{array}
$$

\section{HASIL DAN PEMBAHASAN}

\section{Peramalan Produksi Padi Kabupaten Lamongan}

Untuk meramalkan produksi padi di Kabupaten Lamongan maka dibutuhkan empat tahapan yaitu:

\section{Identifikasi Model}

Produksi padi di Kabupaten Lamongan cenderung stabil bahkan mengalami peningkatan. Pola produksi padi Kabupaten Lamongan dari tahun 1983 sampai 2012 dapat dilihat pada gambar 1 .

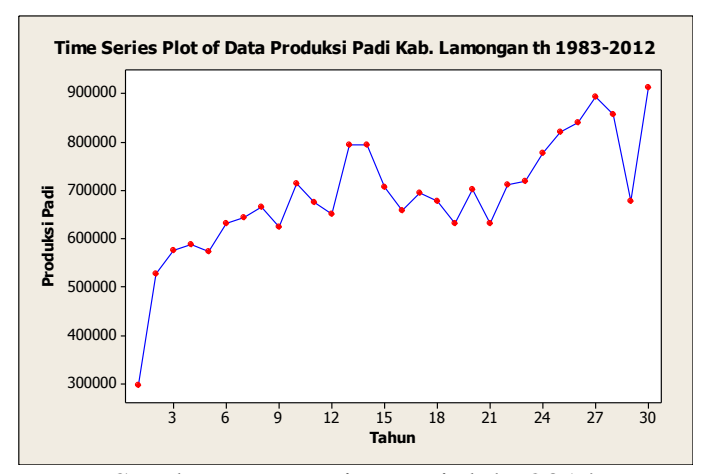

Sumber: Data Primer Diolah, 2014

Gambar 1. Pola Data Produksi Padi Kab. Lamongan Tahun 1983-2012

Dari gambar 1 bisa diketahui bahwa pola produksi padi di Kabupaten Lamongan tahun 1983 sampai 2012 merupakan data yang tidak stasioner, karena masih ada perubahanperubahan tingkat produksi seiring perubahan waktu. Selain dilihat dari plot data untuk mengetahui karakteristik data juga bisa diamati dari koefisien Autocorellation Function (ACF) dan PartialAutocorrelation Function (PACF).

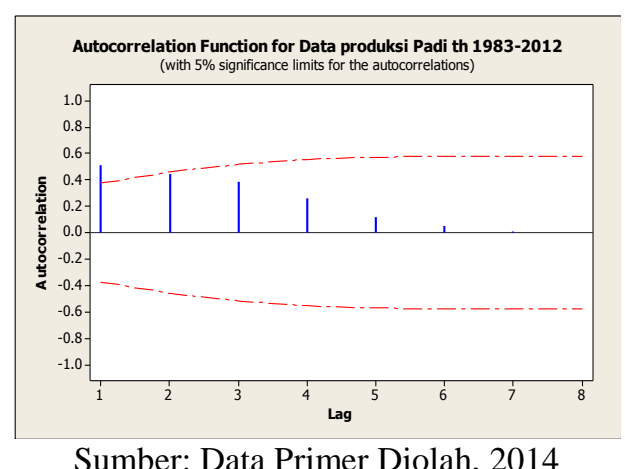

Gambar 2. Fungsi Autokorelasi Produksi Padi Kabupaten Lamongan th 1983-2012

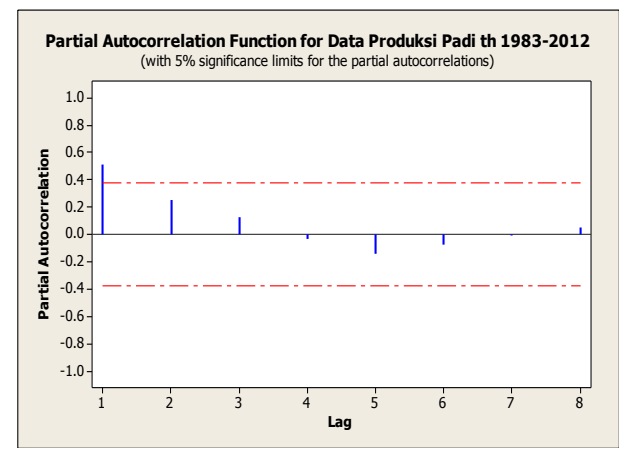

Sumber: Data Primer Diolah, 2014

Gambar 3. Fungsi Autokorelasi Produksi Padi Kabupaten Lamongan th 1983-2012 
Dari gambar 2 dan 3 dapat diketahui bahwa antara koefisien autokorelasi berbeda secara signifikan dari nol dan terus mengecil mendekati nol. Sedangkan pada semua koefisien autokorelasi parsial terus mendekati nol setelah lag pertama. Dari plot PACF juga dapat diidentifikasi bahwa terdapat unsur musiman dalam data, karena dapat dilihat adanya pergantian lag positif menjadi negatif pada lag ke 4. Menurut Hatidja (2011), koefisien autokorelasi berbeda secara signifikan dari nol dan mengecil secara berlahan sedangkan semua koefisien autokorelasi mendekati nol setelah lag pertama maka data tersebut tidak stasioner. Dari kedua karakteristik tersebut dapat disimpulkan bahwa data tersebut tidak bersifat stasioner.

Sedangkan untuk meramalkan data menggunakan metode ARIMA diperlukan data yang stasioner, sehingga untuk menjadikan data stasioner diperlukan proses differencing (metode pembedaan). Hasil proses differencig dapat dilihat pada gambar berikut.

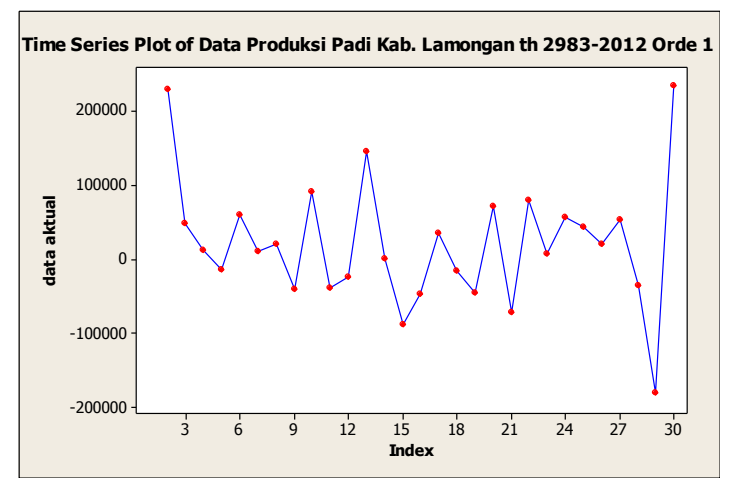

Sumber: Data Primer Diolah, 2014

Gambar 4. Data Produksi Padi Kabupaten Lamongan tahun1983-2012 Selisih Orde 1

\section{Estimasi Model}

Setelah data stasioner maka langkah selanjutnya adalah estimasi model yaitu mencari model ARIMA terbaik yang akan digunakan dalam meramalkan produksi padi. Estimasi model ini dilakukan dengan cara memasukkan berbagai parameter yang ada dalam model ARIMA Musiman yaitu parameter p, d, q, P, D, Q, S. Dimana p adalah derajat autoregressive (AR), d adalah tingkat proses differencing, q adalah derajak moving average (MA), $\mathrm{P}$ adalah derajat autoregressive (AR) musiman, D adalah tingkat proses differencing musiman, $\mathrm{Q}$ adalah derajak moving average (MA) musiman dan s adalah periode musiman. Karena d dan D telah diketahui yaitu 1, dan s adalah 4, maka pada model ARIMA adalah ARIMA (p.1.q)(P,1,Q) ${ }^{4}$. Sehingga model yang kemungkinan digunakan adalah ARIMA $(0,1,1)(1,1,0)^{4}$, ARIMA $(0,1,1)(0,1,1)^{4}$, ARIMA $(1,1,0)(1,1,0)^{4}$, dan ARIMA $(1,1,0)(0,1,1)^{4}$.

\section{Evaluasi Model}

Dari kemungkinan yang telah dievaluasi maka diperoleh model terbaik yaitu ARIMA $(1,1,0)(0,1,1)^{4}$ hasil dari diagnostik ARIMA $(1,1,0)(0,1,1)^{4}$ adalah plot ACF dan PACF dapat dilihat pada gambar 6 dan gambar 7 .

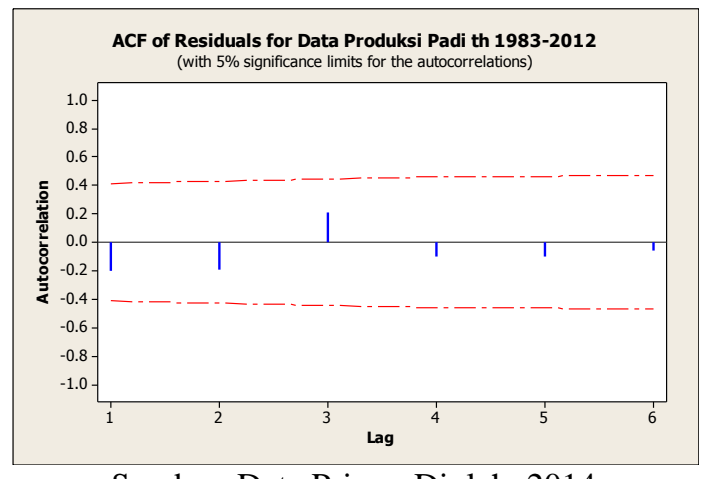

Sumber: Data Primer Diolah, 2014

Gambar 5. Fungsi Autokorelasi Data Produksi Padi Kab. Lamongan th 1983-2012 Selisih Orde 1

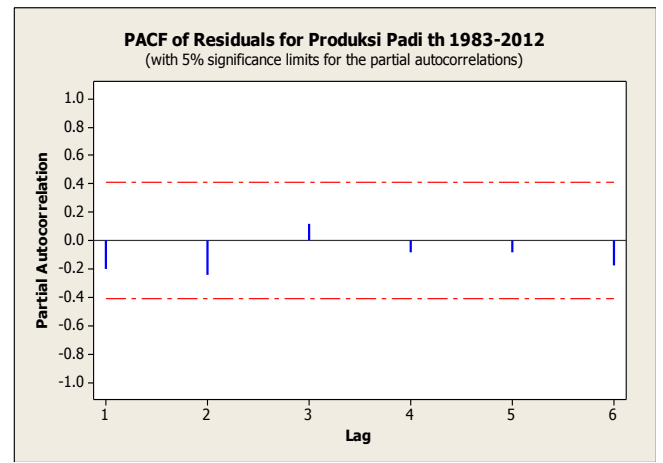

Sumber: Data Primer Diolah, 2014

Gambar 6. Fungsi Partial Autokorelasi Data Produksi Padi Kab. Lamongan th 1983-2012 Selisih Orde 1

Dari tabel ACF dan PACF diatas memiliki kesamaan yaitu sama-sama tidak ada garis warna biru yang melampaui garis warna merah. Dengan demikian maka model ARIMA 
$(1,1,0)(0,1,1)^{4}$ dapat digunakan untuk meramalkan produksi padi Kabupaten Lamongan. Dan dapat dirumuskan persamaan peramalan produksi padi Kabupaten Lamongan adalah sebagai berikut :

$\mathrm{Y}_{\mathrm{t}}=\mathrm{Y}_{\mathrm{t}-1}-0,3041 \mathrm{Y}_{\mathrm{t}-1}+\mathrm{Y}_{\mathrm{t}-4}+0,3041 \mathrm{Y}_{\mathrm{t}-5}-$ $0.3041 \mathrm{Y}_{\mathrm{t}-6}+\mathrm{e}_{\mathrm{t}}-0,8612 \mathrm{e}_{\mathrm{t}-\mathrm{6}}+\mathrm{e}$

Dari model ARIMA $(1,1,0)(0,1,1)^{4}$ juga dapat diperoleh plot data produksi padi Kabupaten Lamongan tahun 1983 sampai 2012 sebenarnya, prediksi, batas maksimal serta baras minimal produksi padi sebagai berikut :

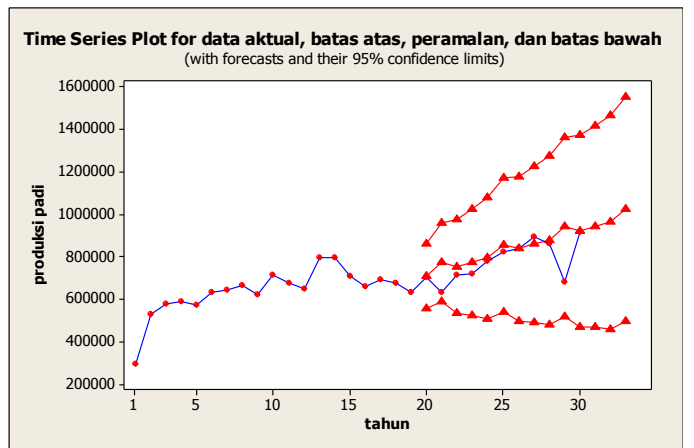

Sumber: Data Primer Diolah, 2014

Gambar 7. Plot Data Produksi Padi Sebenarnnya,

Batas Atas, Peramalan dan Batas Bawah Produksi Padi

Dari gambar 7 dapat dilihat bahwa antara plot data produksi padi sebenarnya saling bersinggunngan dengan plot data peramalan, sehingga dapat dikatakan bahwa model ARIMA $(1,1,0)(0,1,1)^{4}$ layak digunakan untuk menghitung peramalan produksi padi Kabupaten Lamongan untuk beberapa tahun kedepan.

4. Peramalan dengan Model

Dari model ARIMA $(1,1,0)(0,1,1)^{4}$ didapatkan hasil sebagai berikut :
Tabel 3. Hasil Peramalan Produksi Padi

\begin{tabular}{ccccc}
\hline $\begin{array}{c}\text { Perio } \\
\text { de }\end{array}$ & Forecast & Lower & Upper & Actual \\
\hline 2003 & 706.675 & 554.528 & 858.821 & 631.602 \\
2004 & 773.209 & 587.844 & 958.574 & 711.504 \\
2005 & 752.983 & 532.193 & 973.774 & 719.309 \\
2006 & 774.577 & 525.320 & 1.023 .834 & 776.285 \\
2007 & 793.618 & 508.667 & 1.078 .568 & 819.831 \\
2008 & 855.597 & 541.863 & 1.169 .332 & 839.393 \\
2009 & 836.756 & 495.860 & 1.177 .652 & 892.613 \\
2010 & 857.929 & 492.111 & 1.223 .747 & 857.637 \\
2011 & 877.097 & 480.179 & 1.274 .016 & 678.043 \\
2012 & 939.038 & 515.585 & 1.362 .491 & 911.854 \\
2013 & 920.209 & 471.137 & 1.369 .281 & \\
2014 & 941.378 & 468.261 & 1.414 .496 & \\
2015 & 960.548 & 457.745 & 1.463 .350 & \\
2016 & 1.022 .488 & 493.699 & 1.551 .277 & \\
\hline
\end{tabular}

Sumber: Data primer diolah, 2014

Dari hasil peramalan dapat diketahui bahwa produksi padi di Kabupaten Lamongan akan terus mengalami peningkatan, dan pada tahun 2016 produksi padi di Kabupaten Lamongan mencapai 1.022 .488 ton. Jika digambarkan dengan grafik maka sebagai berikut :

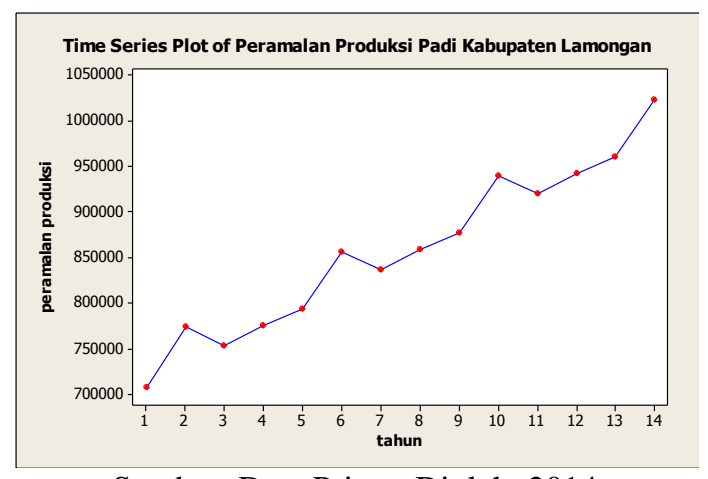

Sumber: Data Primer Diolah, 2014

Gambar 8. Plot Peramalan Produksi padi Kabupaten Lamongan

Dengan diketahuinya peramalan produksi padi yang terus mengalami peningkatan sampai tahun 2016, maka diperlukan upaya yang dapat mendorong peningkatan tersebut. Beberapa peluang yang dapat dimanfaatkan untuk meningkatkan produksi padi di Kabupaten Lamongan yaitu 
pemanfaatan 904 Ha lahan kering yang ada di Kecamatan Sugio menjadi lahan produksi padi, menjadikan sistem irigrasi setengah teknis menjadi teknis, memberikan pengetahuan kepada para petani tentang penggunaan bibit unggul sehingga mereka tidak memakai bibit turunan pada musim tanam sebelumnya, mendukung para petani untuk ikut serta dalam kelompok tani, mendorong para petani untuk ikut serta dalam penyuluhan pertanian dan memberikan bantuan modal kepada para petani.

\section{Faktor-Faktor yang Mempengaruhi Produksi Padi di Kabupaten Lamongan}

Upaya untuk meningkatkan jumlah produksi padi yang telah diramalkan dapat juga dilakukan dengan mengetahui faktor produksi. Untuk mengetahui faktor-faktor yang mempengaruhi produksi padi di Kabupaten Lamongan maka digunakan fungsi produksi Cobb-Douglas. Analisis yang digunakan adalah analisis regresi berganda dengan menggunakan Software SPSS 16.

Uji statistik regresi berganda ini menggunakan metode kuadrat terkecil biasa (Ordinary Least Squares/ OLS), dalam metode ini dibutuhkan beberapa asumsi supaya hasil yang diperoleh bersifat BLUEdapat (Beast Linier Unbiased Estimator).

\section{Uji Normalitas}

Uji normalitas digunakan untuk mengetahui apakah dalam model regresi antara variabel dependen dan independen keduanya mempunyai distribusi normal atau tidak. Dari hasil penelitian ini diketahui nilai signifikansi pada kolom Kolmogorov-Smirnov dari masingmasing variabel hasil produksi, luas lahan, bibit, pestisida, tenaga kerja dan modal memiliki nilai signifikansi lebih besar dari 0,05 . Sehingga dapat disimpulkan bahwa data berdistribusi normal. Menurut Fatoni dan Sumarsono (2013), jika signifikansi variabel independen memiliki nilai signifikansi lebih dari 5\%, dapat dikatakan bahwa data yang digunakan dalam penelitian berdistribusi normal.

\section{Uji Linieritas}

Uji Linieritas digunakan untuk mengetahui linier atau tidaknya hubungan antara variabel independen terhadap variabel dependen. Jika nilai signifikansi kurang dari 0,05 berarti hubungan antara variabel dependen dan independen adalah linier (Dewi dan Indrawati, 2014). Dari hasil penelitian ini diketahui nilai signifikansi dari masing-masing variabel luas lahan, bibit, pestisida, tenaga kerja dan modal memiliki nilai signifikansi lebih kecil dari 0,05. Sehingga dapat disimpulkan bahwa masingmasing variabel independen memiliki hubungan yang linier terhadap variabel dependen.

\section{Uji Autokorelasi}

Uji autokorelasi digunakan untuk mengetahui apakah terdapat korelasi antara kesalahan pengganggu pada periode ke- $x$ dengan kesalahan pengganggu periode sebelumnya. Berdasarkan uji autokorelasi diatas diketahui nilai DW yaitu 1,756 dan nilai dU yaitu 1,7274 . Berarti nilai DW diantara nilai dU dan 4-dU $(1,7274<2,022<2,2746) \quad$ sehingga dapat disimpulkan bahwa model bebas dari autokorelasi. Menurut Damayanti (2013), jika nilai DW berada antara nilai dU dan 4-dU maka tidak terjadi autokorelasi.

\section{Uji Multikolinieritas}

Uji multikolinieritas digunakan untuk mengetahui apakah ada hubungan linier antara variabel independen satu dengan variabel independen yang lain. Berdasarkan hasil analisis diperoleh nilai tolerance masingmasing model luas lahan, pupuk urea, tenaga kerja dan modal diatas 0,1 , sedangkan nilai VIF dibawah 10. Sehingga dapat disimpulkan model bebas dari masalah multikolinieritas. Menurut Setyorini (2012), jika nilai tolerance menunjukan kurang dari $10 \%$, maka tidak ada korelasi anatar variabel independen. Dan jika nilai VIF tidak ada yang menunjukkan diatas 10 maka dinyatakan tidak ada gejala multikolinieritas antar variabel independen pada model.

\section{Uji Heteroskedastisitas}

Uji heteroskedastisitas digunakan untuk mengetahui apakah ada ketidaksamaan varian dan residual pada Berdasarkan hasil uji heteroskedastisitas diperoleh nilai signifikansi masing-masing variabel diatas 0,05 , sehingga dapat diartikan bebas dari gejala heteroskedastisitas. Menurut Arifiyani (2012), jika nilai signifikansi variabel lebih besar dari 
0,05 maka dapat disimpulkan dalam model regresi tidak terjadi gejala heteroskedastisitas.

Setelah dilakukan uji asumsi klasik maka langkah yang selanjutnya yaitu uji statistik yang terdiri dari: (1) Uji koefisien determinasi $\left(\mathrm{R}^{2}\right)$, (2) Uji koefisien regresi secara simultan (uji F), dan (3) Uji koefisien secara parsial (uji t).

Tabel 4. Hasil Uji Regresi

\begin{tabular}{lccc}
\hline Varabel & $\mathrm{B}$ & $\mathrm{t}$ & Sig. \\
\hline Constant & 0.656 & 0.354 & 0.725 \\
Luas Lahan & 0.396 & 3.185 & 0.002 \\
Pupuk Urea & 0.197 & 2.858 & 0.006 \\
Tenaga Kerja & 0.277 & 2.333 & 0.023 \\
Modal & 0.385 & 2.935 & 0.005 \\
\hline Adjusted $R^{2}$ & 0,786 & & \\
$\mathrm{~F}_{\text {hitumg }}$ & 55.162 & & \\
\hline
\end{tabular}

Sumber : Data Primer Diolah, 2014

Berdasarkan hasil uji regresi maka didapat persamaan sebagai berikut :

$\mathrm{LnQ}=0,656+0,396 \operatorname{lnL}+0,197 \ln \mathrm{P}_{\text {Urea }}+$ $0,277 \ln \mathrm{TK}+0,385 \ln \mathrm{M}+\varepsilon$

Dimana : $\mathrm{Q}$ adalah hasil produksi, $\mathrm{L}$ adalah luas lahan, $\mathrm{P}_{\text {Urea }}$ adalah pupuk urea, TK adalah tenaga kerja, $\mathrm{M}$ adalah modal dan cadalah error term.

\section{Uji koefisien determinasi $\left(\mathbf{R}^{2}\right)$}

Dari penelitian diketahui nilai adjusted $R$ square adalah 0,786 atau $78,6 \%$. Sehingga dapat disimpulkan model layak digunakan karena lebih dari 50\%, dan dapat diartikan bahwa variabel luas lahan, pupuk urea, tenaga kerja dan modal mampu menjelaskan variabel hasil produksi $78,6 \%$ dan $21,4 \%$ dijelaskan oleh variabel lain diluar model. Ini sama dengan penelitian yang dilakukan oleh Nedi, dkk (2013), dimana diketahui nilai adjust $R^{2}$ sebesar 0,928 atau $92,8 \%$ yang berarti variabel luas lahan, bibit, tenaga kerja, pupuk ure, phonska, Sp-36, kandang, ZA dan pestisida. Sedangkan sisanya dijelaskan oleh faktor-faktor yang tidak ada dalam penelitian. Hasil koefisien determinasi dapat dilihat pada tabel 32.

\section{Uji koefisien regresi secara simultan (uji F)}

Uji $F$ ini digunakan untuk mengetahui pengaruh variabel independen secara keseluruhan terhadap variabel dependen. Berdasarkan hasil uji $\mathrm{F}$ diperoleh nila $\mathrm{F}_{\text {hitung }}$ sebesar 55,162 dan diketahui nilai $\mathrm{F}_{\text {tabel }}$ sebesar 2,53 , berarti nilai $F_{\text {hitung }}(55,162)>F_{\text {tabel }}(2,53)$. Dan dikrtahui nilai sig sebesar 0,000 atau lebih kecil dari 0,05 . Sehingga dapat disimpulkan bahwa variabel luas lahan, pupuk urea, tenaga kerja dan modal berpengaruh terhadap hasil produksi padi di Kabupaten Lamongan. Ini seperti penelitian yang dilakukan Rizwan, dkk (2011), dimana uji F sebesar 0,00 dengan tingkat kesalahan 5\% menunjukkan model regresi yang sangat berarti. Ini berarti tujuh variabel faktor produksi ukuran kapal, daya mesin, panjang jaring pukat cincin, dalam jaring pukat cincin, jumlah awak kapal, BBM dan jumlah lampu secara bersama berpengaruh nyata terhadap hasil tangkapan nelayan.

\section{Uji koefisien secara parsial (uji t)}

Uji $t$ digunakan untuk mengetahui pengaruh masing-masing variabel independen terhadap variabel dependen. Hal ini dapat diketahui dari nilai $t_{\text {hitung }}$ dan nilai signifikan. Dengan diketahui nilai df sebanyak 59 (60-1) dan $t_{\text {hitung }}$ sebesar 2,001 dengan taraf kepercayaan 95\%. Hasil uji t dapat dilhat pada tabel 35.

\section{A. Luas Lahan}

Nilai koefisien variabel luas lahan pada analisis regresi memiliki tanda positif yaitu sebesar 0,396 dan nilai $t_{\text {hitung }}$ sebesar 3,185. Dapat diartikan bahwa nilai $t_{\text {hitung }}$ lebih besar dari nilai $t_{\text {tabel }}$ yaitu 2,001. Nilai koefisien sebesar 0,396 menunjukkan bahwa dengan penambahan luas lahan sebesar $1 \%$ dapat meningkatkan hasil produksi sebesar 0,396\%. Dari seluruh petani responden, antara petani yang memiliki luas lahan sempit $(<0,5 \mathrm{Ha})$, sedang $(0,5-1 \mathrm{Ha})$ dan luas ( $>1 \mathrm{Ha}$ ) menghasilkan produksi padi yang berbeda. Dimana petani yang memiliki luas lahan sempit $(<0,5 \mathrm{Ha})$ memiliki rata-rata hasil produksi 2,416 ton, sedang $(0,5-1) 7,825$ ton dan luas (>1 Ha) 8,778 ton. Ini menunjukkan bahwa semakin luas lahan yang dimiliki oleh petani maka hasil produksi padi yang diperoleh petani maka semakin banyak. Karena menurut Mubyarto dalam Darwanto (2010), lahan garapan adalah salah satu faktor dalam usahatani yang memiliki produktivitas, semakin sedikit lahan garapan yang ada di suatu daerah maka hasil produksi dan pendapatan usahatani tersebut juga semakin sedikit. 
Penelitian ini sejalan dengan penelitian Damayanti (2013), variabel luas lahan memiliki koefisien bertanda positif yaitu 0,982617 artinya setiap peningkatan penggunaan luas lahan $1 \%$ akan mampu meningkatkan produksi padi sawah sebesar 0,98361\%. Dan ini munjukkan semakin luas garapan usahatani yang dikelolah oleh petani akan meningkatkan produksinya. Dan menurut Fitrah (2013), luas lahan adalah faktor yang memiliki pengaruh sangat nyata terhadap produksi padi dengan taraf kepercayaan $99 \%$, yang dilihat dari nilai thit $(7,8491083)$ lebih besar dari nilai t-tab $(2,457)$.

Sedangkan penelitian Maridelana, dkk (2014), menyatakan bahwa luas lahan pada usahatani kopi memiliki nilai koefisien regresi 0,666 dengan signifikansi 0,96 . Ini memiliki arti bahwa luas lahan memiliki pengaruh nyata terhadap produksi kopi pada taraf kepercayaan 90\% dan arah hubungannya adalah negatif. Dimana kenaikan luas lahan sebesar $1 \%$ menyebabkan penurunan keuntungan usahatani kopi sebear $0,666 \%$.

\section{B. Pupuk Urea}

Nilai koefisien pupuk urea pada analisis regresi memiliki tanda positif yaitu sebesar 0,197 dan nilai $\mathrm{t}_{\text {hitung }}$ sebesar 2,858. Dapat diartikan bahwa nilai $t_{\text {hitung }}$ lebih besar dari nilai $t_{\text {tabel }}$ yaitu 2,001. Ini menunjukkan bahwa semakin banyak pupuk urea yang digunakan oleh petani maka semakin banyak pula hasil produksi yang diperoleh. Penggunaan pupuk urea dengan takaran dan dosis yang tepat mampu mengoptimalkan pertumbuhan padi. Nilai koefisien sebesar 0,197 menunjukkan bahwa jika pengguaan pupuk urea ditambah sebesar $1 \%$ maka mampu meningkatkan hasil produksi padi sebesar $0,197 \%$. Sehingga dengan meningkatkan penggunaan pupuk urea akan dapat meningkatkan produksi padi. Karena dosis yang dianjurkan oleh Dinas Pertanian Kabupaten Lamongan yaitu $350 \mathrm{~kg} / \mathrm{Ha}$, sedangan rata-rata pupuk urea yang digunakan oleh petani hanya sebesar $220 \mathrm{~kg} / \mathrm{Ha}$. Ini menunjukan bahwa takaran dosis yang digunakan petani masih jauh dibawah anjuran. Kondisi ini terjadi karena seringkali petani mengalami kesulitan untuk mendapatkan pupuk urea pada saat pemupukan, karena kelangkaan pupuk urea di pasar sekitar desa penelitian. Selain itu petani sebagian petani juga menghadapi keterbatasan modal sehingga tidak mampu memberikan pupuk urea sesuai dengan anjuran.

Pupuk $\mathrm{N}$ memiliki peranan yang sangat penting untuk meningkatkan produksi padi sawah, dan pupuk $\mathrm{N}$ dapat diperoleh dari pupuk urea. Tapi, hanya $30 \%$ dari yang diberikan pupuk $\mathrm{N}$ yang dapat diserap oleh padi (Dobermann dalam Siregar dan Marzuki 2011). Pemberian pupuk $\mathrm{N}$ dengan dosis yang tepat akan mampu mengoptimalkan pertumbuhan panjang, lebar dan luas daun, sehingga mampu meningkatkan produktivitas padi. Tapi jika pupuk $\mathrm{N}$ tidak digunakan tidak tepat dapat mencemari tanah. Pemberian pupuk urea dilakukan ketika pemupukan pertama dan kedua, yaitu pada saat padi berumur 10 hari dan 25 hari setelah tanam, karena pada usia tersebut tanaman padi berada pada masa pertumbuhan batang dan daun, sehingga dengan pemberian pupuk urea pertumbuhan batang dan daun akan maksimal. Sedangkan pemupukan ketiga biasanya dilakukan pada usia 30 hari setelah masa tanam, tapi pada pemupukan ketiga ini tidak digunakan pupuk urea karena padi telah masuk dalam fase pembuahan.

Penelitian ini sejalan dengan penelitian Damayanti (2013), dimana variabel pupuk urea yang memiliki koefisien positif 0,077450 memiliki arti bahwa penggunaan pupuk urea meningkat $1 \%$ maka meningkatkan produksi sebesar $0,077450 \%$. Sehingga peningkatan penggunaan pupuk urea masih dimungkinkan mampu meningkatkan produksi. Ini karena pupuk urea memiliki nilai positif dan menunjukkan bahwa penggunaan pupuk urea di daerah penelitian belum maksimal.

Sedangkan penelitian yang dilakukan Isyanto (2012), menyatakan bahwa penggunaan pupuk pada usahatani padi tidak memiliki pengaruh yang signifikan. Penggunaan pupuk kandang memiliki nilai koefisien bertanda negatif, yang berarti penggunaan pupuk kandang berlebihan sehingga harus dikurangi. Sedangkan penggunaan pupuk kimia (urea, KCL, SP 36) memiliki nilai koefisien bertanda positif, sehingga pupuk kimia harus ditambah.

\section{Tenaga Kerja}

Nilai koefisien tenaga kerja pada analisis regresi memiliki tanda positif yaitu sebesar 0,277 dan nilai $t_{\text {hitung }}$ sebesar 2,333. Dapat diartikan bahwa nilai $t_{\text {hitung }}$ lebih besar dari nilai 
$\mathrm{t}_{\text {tabel }}$ yaitu 2,001. Ini menunjukkan bahwa semakin banyak tenaga kerja yang digunakan oleh petani maka semakin banyak usahatani yang dapat dilakukan dan semakin banyak pula hasil produksi yang diperoleh. Nilai koefisien sebesar 0,277 menunjukkan bahwa jika pengguaan tenaga kerja ditambah sebesar $1 \%$ maka mampu meningkatkan hasil produksi padi sebesar $0,277 \%$.

Tenaga kerja yang digunakan di daerah penelitian berasal dari dalam dan luar keluarga, tetapi yang banyak berperan aktif adalah tenaga kerja keluarga. Pada proses pemupukan, penyemprotan dan penyiangan dilakukan oleh tenaga kerja keluarga dengan jumlah yang terbatas, karena sebagian besar pekerjaan tersebut hanya dilakukan oleh petani yang bersangkutan. Sehingga intensitas pemupukan, penyemprotan dan penyiangan kurang optimal. Dimana penyiangan yang seharusnya dilakukan pada minggu ketiga dan keenam setelah tanam hanya dilakuan ketika petani yang bersangkutan tidak ada kegiatan yang lain seperti penyemprotan dan pemupukan. Proses penyiangan ini biasanya dilakukan pada pagi hari sampai sebelum Dhuhur dan kembali pada keesokan harinya jika tidak ada kegiatan lain. Sedangan untuk proses tanam dan panen menggunakan tenaga kerja luar, karena pada proses ini membutuhkan tenaga kerja cukup banyak sehingga jika hanya menggunakan tenaga kerja keluarga akan membutuhkan waktu yang lama. Namun menurut Wahyuningsih (2012), ketersediaan tenaga kerja dalam keluarga adalah potensi besar yang dapat dimanfaatkan dalam melakukan usahatani, karena pemanfaatan tenaga kerja dalam rumah tangga mampu menekan biaya yang harus dikeluarkan sebagai upah tenaga kerja luar keluarga.

Penelitian ini sejalan dengan penelian yang dilakukan oleh Nedi, dkk (2013), variabel tenaga kerja memiliki pengaruh yang nyata terhadap produksi jagung dengan nilai koefsien regresi sebesar 0,340. Dan memiliki nilai $t_{\text {hitung }}$ 2,084 yaitu lebih besar dari nilai $t_{\text {tabel }}$ sebesar 1,982. Sedangkan menurut Yulianto (2005), nilai koefisien biaya tenaga kerja memiliki nilai negatif yaitu $-0,249$ artinya biaya tenaga kerja memiliki hubungan yang negatif terhadap pendapatan usahatani semangka. Hal ini dikarenakan tenaga kerja yang digunakan telah melebihi dari kebutuhan yang ada sehingga berpengaruh pada penerimaan.

\section{Modal}

Nilai koefisien modal pada analisis regresi memiliki tanda positif yaitu sebesar 0,385 dan nilai $t_{\text {hitung }}$ sebesar 2,935. Dapat diartikan bahwa nilai $t_{\text {hitung }}$ lebih besar dari nilai $t_{\text {tabel }}$ yaitu 2,001. Nilai koefisien sebesar 0,385 menunjukkan bahwa jika pengguaan modal ditambah sebesar $1 \%$ maka mampu meningkatkan hasil produksi padi sebesar $0,385 \%$. Ini menunjukkan bahwa modal yang digunakan masih belum maksimal, sehingga penambahan modal sangat memungkinkan dapat meningkatkan hasil produksi padi. Di daerah penelitian rata-rata biaya yang harus dikeluarkan oleh petani dalam menjalankan usahataninya sebesar Rp. 4.636.700, karena sebagian besar petani memiliki luas lahan dibawah $1 \mathrm{Ha}$. Sedangkan modal yang digunakan oleh petani berasal dari hasil panen sebelumnya. Di daerah penelitian belum terbentuk koperasi yang siap menyediakan modal kepada para petani, dan kelompok tani yang sudah ada juga tidak memfasilitasi peminjaman modal kepada anggotanya. Padahal menurut Nainggolan dan Murdy (2013), Program Penguatan Modal Petani (PMP) memiliki pengaruh positif dan nyata terhadap peningkatan produksi dan pendapatan petani padi di Kabupaten Tanjung Jabung Barat. Ini menunjukkan bahwa PMP memiliki pengaruh kepada petani yang menerima dana program PMP, sehingga petani dapat mengoptimalkan input produksi dibandingkan dengan petani yang tidak menerima dana dari program PMP.

Salah satu upaya yang dapat dilakukan untuk memberikan modal kepada para petani yaitu dengan membentuk lembaga pengkreditan desa (LPD) dengan bunga yang rendah. Dimana LPD ini berbeda dengan koperasi, karena LPD merupakan lembaga yang berasal dari masyarakat lokal. Seperti halnya yang telah dilakukan oleh para petani di Desa Baturiti Kabupaten Tabanan, Bali. Menurut Elizabeth dan Anugrah (2009), di desa tersebut terdapat Lembaga Pengkreditan Desa (LDP) merupakan institusi yang tumbuh berdasarkan ikatan adat budaya lokal. Kunci utama dari lembaga ini yaitu dukungan masyarakat yang kuat antara masyarakat Desa Adat dan Banjar. Dimana sebagian keuntungan 
usahanya akan masuk kedalam kas pemerintahan Desa Adat yang selanjutnya akan digunakan sebagai sumber pengkreditan dan kebutuhan sarana dan prasaran umum bersama dan kelompok tanilah yang berfungsi sebagai wadah pelaksanaan program ini. Tidak hanya kegiatan pengkreditan, komonitas petani yang ada di daerah ini juga tercemin pada aktivitasaktivitas yang diselenggarakan oleh kelompok tani seperti diskusi tentang budidaya dan pemasaran sayuran, arisan rutin kelompok tani yang diadakan setiap bulan, iuran gabah 2 $\mathrm{kg}$ /are setiap musim panen dan pelatihan pengolahan produk pertanian. Dari kegiatankegiatan yang diadakan oleh kelompok tani ini mampu membawa desa Baturiti sebagai desa mandiri yang memiliki sumber ekonomi sendiri.

Penelitian ini seperti penelitian yang dilakukan Yulianto (2005), dimana biaya produksi memiliki pengaruh positif terhadap pendapatan usahatani semangka di Kec. Samarinda Utara. Ini berarti bahwa peningkatan penggunaan biaya produksi mampu meningkatkan pendapatan petani, dimana diketahui nilai koefisien biaya produksi yaitu 4,696 yang menunjukkan bahwa peningkatan biaya produksi sebesar $1 \%$ akan meningkatkan pendapatan petani sebesar $4,696 \%$.

\section{PENUTUP}

\section{Kesimpulan}

Berdasarkan hasil dari penelitian ini maka dapat disimpulkan: (1) Hasil peramalan dengan menggunakan metode ARIMA, diramalkan produksi padi di Kabupaten Lamongan pada tahun 2016 mengalami peningkatan yaitu sebesar 1.022.488 ton.(2) Faktor-faktor produksi yang berpengaruh nyata terhadap produksi padi di Kabupaten Lamongan yaitu luas lahan, pupuk urea, tenaga kerja dan modal. Sehingga jika masing-masing variabel tersebut ditingkatkan maka mampu meningkatkan hasil produksi padi.

\section{Saran}

Kabupaten Lamongan berpotensi untuk dapat meningkatkan produksi padinya sebesar 1.02 juta ton pada tahun 2016. Cara yang dapat dilakukan adalahmemberikan pinjaman modal berbunga rendah karena dengan modal tersebut maka petani dapat mengintensifkan penggunaan pupuk urea sampai pada batas yang dianjurkan yaitu $350 \mathrm{~kg} / \mathrm{Ha}$. Selain itu petani juga dapat menambah jumlah tenaga kerja di luar keluarga sehingga usahatani padi bisa lebih intensif. Cara lain yang dapat ditempuh oleh pemerintah adalah dengan memperbaiki sistem irigrasi setengah teknis menjadi sistem irigasi teknis.

\section{DAFTAR PUSTAKA}

Adiratma, R.E. 2004. Stop Tanaman Padi. Penebar Swadaya. Jakarta.

Arifiyani, H. A., dan Sukirno. 2012. Pengaruh Pengendalian Intern, Kepatuhan dan Kompensasi Manajemen terhadap Perilaku Etis Karyawan (Studi Kasus PT Adisatria Abadi Yogyakarta). Jurnal Nominal Volume 1 Nomor 1 tahun 2012.

BKPM. 2012. Gambaran Wilayah Kabupaten Lamongan. Badan Koordinasi Penanaman Modal. Lamongan.

BPS. 2013. Kabupaten Lamongan dalam Angka. Dinas Pertanian dan Kehutanan. Lamongan.

Bustaman, A. 2003. Analisis integrasi pasar beras di Indonesia. Skripsi. Jurusan ilmu sosial ekonomi pertanian. Fakultas pertanian. Institute Pertanian Bogor.

Damayanti, L. 2013. Faktor-faktor yang Mempengaruhi Produksi, Pendapatan dan Kesempatan Kerja pada Usahatani Padi Sawah di Daerah Irigasi ParigiMoutong. Jurnal SEPA Vol. 9 No. 2 Februari 2013:249-259.

Dewi, I. A. G. B. P., dan Komang R. I. 2014. Perilaku Mencatat dan Kemampuan Memori pada Proses Belajar. Jurnal Psikologi Udayana Vol. 1, No. 2, 241250.

Elizabeth, R., dan Iwan S. A. 2009. Sistem Kelembagaan Komonitas Petani Sayuran di Desa Baturti, Kabupaten Tabanan, Provinsi Bali. Seminar Nasional 
Peningkatan Daya Saing Agribisnis Berorientasi Kesejahteraan Petani. Bogor: 14 Oktober 2009.

Fatoni, Z., dan Hadi S. 2013. Dampak Fluktuasi Indeks Harga Saham dan Ekspor Netto terhadap Kurs Rupiah pada Masa Krisis Global. Jurnal Ekonomi dan Studi Pembangunan Vol. 5, No. 1, Maret 2013.

Fitrah, H. 2013. Input Faktor yang mempengaruhi Produksi dan Kelayakan Usahatani Padi Sawah Pasang Surut di Desa Karang Buah Kecamatan Belawang Kabupaten Barito Kuala Kalimantan Selatan. Media Sains, Volume 6 Nomor 2, Oktober 2013.

Hatidja, D. 2011. Penerapan Model ARIMA untuk Memprediksi Harga Saham PT. Telkom, Tbk. Jurnal Ilmiah Sains Vol. 11 No. 1, April 2011.

Hossain, Md. K., Anton A. K., Md. Azizul B., and Adli M. 2012. Stochastic Frontier Approach and Data Envelopment Analysis to Total Factor Productivity and Efficiency Meansurement of Bangladeshi Rice. PLOS ONE October 2012, Volume 7, Issue 10, e46081.

Hutami, R. P. 2012. Pengaruh Devidend Per Share, Return On Equity dan Net Profil Margin terhadap Harga Saham Perusahaan Industri Manufaktur yang Tercatat di Bursa Efek Indonesia Periode 2006-2010. Jurnal Nominal, Volume 1, Nomor 1, tahun 2012.

Isyanto, A. Y. 2012. Faktor-faktor yang Berpengaruh terhadap Produksi pada Usahatani Padi di Kabupaten Ciamis. CAKRAWALA GALUH Vol. 1. No. 8, Maret 2012.

Luntungan, A. Y. 2012. Analisis Pendapatan Usahatani Tomat Apel di Kecamatan Tompaso Kabupaten Minahasa.Jurnal Ekonomi dan Keuangan Daerah (PEKB) Volume 7 No. 3 Edisi Oktober 2012.
Maridelana, V. P., Yuli H.., dan Ebban B. K. 2014. Fungsi Keuntungan Usahatani Kopi Rakyat di Desa Belatih Kecamatan Kintamani Kabupaten Bangli. Berkalah Ilmiah PERTANIAN volume 1, Nomor 3, Februari 2014, hlm 47-52.

Nainggolan, S., dan Sa'ad M. 2013. Pengkajian Program Penguatan Modal Petani dan Dampaknya terhadap Pendapatan dan Efisiensi Usahatani Padi Sawah di Kabupaten Tanjung Jabung Barat Provinsi Jambi.Seminar Nasional Sains \& Teknologi $V$ Lembaga Penelitian Universitas Lampung.

Nedi, B., Suprapti S., dan Joko S. 2013. Analisis Usahatani Jagung di Kabupaten Grobongan Provinsi Jawa Tengah. Agribusiness Review Vol 1, No. 1 (Desember 2013), hal 33-44. ISSN 23548320.

Nurhayati, A., Darnah A. N., dan Yaripuddin. 2013. Peramalan menggnakan Model ARIMA Musiman dan Verifikasi Hasil Peramalan dengan Grafik Pengendali Moving Range (Studi Kasus: Produksi Air Bersih di PDAM Tirta Kencana Samarinda). Jurnal EKSPONENSIAL Volume 4, Nomor 1, Mei 2013.

Rahmawati, D., dan Ahmad F. 2013. Optimalisasi Sistem Persediaan Bahan Baku Karet Mentah (Lateks) dengan Metode Lot Sizing (Studi Kasus: PT. Abaisiat Raya). Jurnal Optimalisasi Industri, Vol. 12 No. 1, April 2013:317325.

Rizwan., I. S., dan Ratna M. A. 2011. Effect of Production Factors on Purse Seine Fish Capture in the Lampulo Coastal Fisherries Port, Banda Aceh. Jurnal Natural Vol. 11, No. 1, 2011.

Sangarimbun, M dan Sofyan E. 2008. Metode Penelitian Survei. LP3ES. Yogyakarta.

Setyorini, C. T. 2012. Pengaruh Komitmen Organisasi, Budaya Organisasi dan Keterlibatan Kerja terhadap Kinerja Karyawan Baitulmaal Wat Tamwil 
Alviyah Yunianti dan Elys Fauziyah: Perspektif peningkatan produksi padi ...

(BMT). Jurnal Media Riset, Vol. 2 No. 1 Februari 2012.

Siregar, A., dan Ilyas M. 2011. Efisiensi Pemupukan Urea terhadap Serapan dan Peningkatan Produksi Padi Sawah (Oryza sativa L.). Jurnal Budidaya Pertanian, Vol. 7. No. 2, Desember 2011. Halaman 107-112.

Wahyuningsih, Y. M. 2012. Potensi Tenaga Kerja dalam Kelurga terhadap Pendapatan Usahatani Tomat
(Lycopersicon esculentium) di Desa Rantau Keminting Kecamatan Labuanamas Utara Kabupaten Hulu Sungai Tengah Provinsi Kalimantan Selatan. Media Sains, Volume 4 Nomor 1, April 2012.

Yulianto, E. H. 2005. Pengaruh Biaya Saprodi dan Tenaga Kerja terhadap Pendapatan Usahatani Semangka. Jurnal EPP. Vol. 2, No. 2, $2005:$ 24-32. 